\title{
Campsites, forest fires, and entry point distance affect earthworm abundance in the Boundary Waters Canoe Area Wilderness
}

\author{
Todd Wellnitz $^{\text {Corresp., }}{ }^{1}$, Jenna L Barlow ${ }^{1}$, Cory M Dick $^{1}$, Terrance R Shaurette $^{1}$, Brian M Johnson ${ }^{1}$, Troy Wesley ${ }^{1}$, \\ Evan R Weiher ${ }^{1}$ \\ ${ }^{1}$ Biology Department, University of Wisconsin-Eau Claire, Eau Claire, Wisconsin, United States \\ Corresponding Author: Todd Wellnitz \\ Email address: wellnita@uwec.edu
}

Factors controlling the spread of invasive earthworms in Minnesota's Boundary Waters Canoe Area Wilderness are poorly known. Believed to have been introduced by anglers who use them as bait, invasive earthworms can alter the physical and chemical properties of soil and modify forest plant communities. To examine factors influencing earthworm distribution and abundance, we sampled 38 islands across five lakes to assess the effects of campsites, fire, and entry point distance on earthworm density, biomass and species richness. We hypothesized that all three parameters would be greater on islands with campsites, lower on burned islands, and would decrease with distance from the wilderness entry point. In addition to sampling earthworms, we collected soil cores to examine soil organic matter and recorded ground and vegetation cover.

Campsite presence was the single most important factor affecting sampled earthworm communities; density, biomass and species richness were all higher on islands having campsites. Fire was associated with reduced earthworm density, but had no direct effects on earthworm biomass or species richness. Fire influenced earthworm biomass primarily through its negative relationship to groundcover and through an interaction with entry point distance. Entry point distance itself affected earthworm density and biomass. For islands with campsites, earthworm biomass increased with distance from the entry point. 


\section{Campsites, forest fires, and entry point distance affect}

\section{2 earthworm abundance in the Boundary Waters Canoe Area}

\section{Wilderness}

4

5 Todd A. Wellnitz, Jenna L. Barlow, Cory M. Dick, Terrance R. Shaurette, Brian M. Johnson,

6 Troy K. Wesley and Evan R. Weiher

8 Biology Department, University of Wisconsin - Eau Claire, Eau Claire, WI 54701

9

12 Corresponding author:

13 Dr. Todd A. Wellnitz

14 Biology Department

15 University of Wisconsin - Eau Claire Phillips Hall, 345

16 Eau Claire, WI 54701

17 e-mail address: wellnita@uwec.edu 
19 Abstract

Factors controlling the spread of invasive earthworms in the forest ecosystems of

21 Minnesota's Boundary Waters Canoe Area Wilderness are poorly known. Believed to have been

22 introduced by anglers who use them as bait, invasive earthworms can alter the physical and

23 chemical properties of soil and modify forest plant communities. To examine factors influencing

24 earthworm distribution and abundance, we sampled 38 islands across five lakes to assess the

25 effects of campsites, fire, and entry point distance on earthworm density, biomass and species

26 richness. We hypothesized that all three parameters would be greater on islands with campsites,

27 lower on burned islands, and would decrease with distance from the wilderness entry point. In

28 addition to sampling earthworms, we collected soil cores to examine soil organic matter and

29 recorded ground and vegetation cover.

30 Campsite presence was the single most important factor affecting sampled earthworm

31 communities; density, biomass and species richness were all higher on islands having campsites.

32 Fire was associated with reduced earthworm density, but had no direct effects on earthworm

33 biomass or species richness. Fire influenced earthworm biomass primarily through its negative

34 relationship to groundcover and through an interaction with entry point distance. Entry point

35 distance itself affected earthworm density and biomass. For islands with campsites, earthworm

36 biomass increased with distance from the entry point.

38 Introduction

Following the end of the last glaciation 12,000 years ago, northern forests of the presentday United States were believed to have been entirely free of earthworms (Tiunov et al., 2006). 
41 Since the glacial retreat, native earthworm populations have largely remained below the glaciers'

42 southern terminus, but in recent times non-native earthworms from Europe have proliferated and

43 become increasingly common on old glaciated landscape (Callaham et al., 2006; Hopfensperger

$44 \&$ Hamilton, 2015). As non-native earthworms expanded their range north, they have profoundly

45 impacted the northern forest ecosystems that evolved in their absence (Hale, Frelich \& Reich,

46 2005; Frelich et al., 2006). Many earthworms feed on leaf litter and decomposing plant material

47 that accumulates as a spongy layer of duff on the forest floor. The duff layer provides habitat for

48 ground-dwelling animals and understory vegetation and helps prevent soil erosion. Earthworms

49 consume the duff and excrete nutrient-rich castings, which in combination with their bioturbation

50 and mixing of soil layers, can stimulate microbial activity and greatly accelerate soil nutrient

51 cycling (Bohlen et al., 2004a). Although these processes benefit horticultural and agricultural

52 systems (Bertrand et al., 2015; Sharma, Tomar \& Chakraborty, 2017), they can fundamentally

53 alter the functioning of northern forest ecosystems (Bohlen et al., 2004b). Among other

54 detrimental effects, earthworms can alter forest seed banks, kill plant roots, and increase soil

55 compaction, which can lead to increased erosion and nutrient leaching (Costello \& Lamberti,

56 2009; Hopfensperger, Leighton \& Fahey, 2011; Drouin et al., 2014; Nuzzo, Davalos \& Blossey,

57 2015), and negatively affect native flora and fauna (Hale et al., 2008; Loss \& Blair, 2011;

58 Fisichelli et al., 2013; Dobson \& Blossey, 2015).

Non-native earthworms are common in the Boundary Waters, a vast wilderness region of

60 interconnected lakes straddling the Canada-United States border between Ontario and Minnesota

61 (Fig. 1). In northern Minnesota this region has been designated the Boundary Water Canoe Area

62 Wilderness (BWCAW). Known for its pristine lakes and excellent sports fishing, the BWCAW

63 has long been a destination for anglers (Heinselman, 1999), and it is probable that anglers played 
64 an important role in spreading non-native earthworms into the area by using them as fish bait

65 (Cameron, Bayne \& Clapperton, 2007; Hale, 2008; Kilian et al., 2012). Non-native earthworms

66 such as "night crawlers" (Lumbricus terrestris) and "red wigglers" (Lumbricus rubellus or

67 Dendrodrilus rubidus) have been sold as fishing bait for decades and are now abundant in

68 BWCAW forests. It is not unusual for anglers to dump unused bait (Keller et al., 2007; Frelich \&

69 Reich, 2009), and even if the discarded earthworm adults are dead, the soil in which they are

70 packed may contain viable earthworm cocoons that could invade a site. Campsites are likely

71 dumping grounds for unused bait and probable points of earthworm invasion because visitors to

72 the BWCAW are required to stay at designated campsites.

While earthworms are novel to the BWCAW, fire has shaped the region for millennia

74 (Heinselman, 1999). Historically, fire disturbance occurred at 50-100-year intervals, but fire

75 suppression practices over the past century have increased fire intervals to 700 years or more

76 (Heinselman, 1999; Frelich \& Reich, 2009). Forest fire frequency could matter to earthworms

77 because burning away duff and litter layers has the potential for controlling their numbers

78 (Callaham et al., 2003). Fire kills adults that inhabit the leaf litter (i.e., epigeic species) and may

79 reduce the viability of earthworm cocoons in the soil (Ikeda et al., 2015). For soil-dwelling and

80 deep-burrowing earthworms (i.e., endogenic and anecic species), burning away the duff and litter

81 layers would limit food resources, likely starve earthworms, and reduce their fitness (Callaham

82 \& Blair, 1999; Coyle et al., 2017). Despite its potential for earthworm control, only a handful of

83 studies have examined how fire affects earthworm dynamics in North American ecosystems

84 (James, 1982; 1988; Callaham \& Blair, 1999; Callaham et al., 2003; Ikeda et al., 2015), and

85 fewer still have examined earthworm responses to fire in northern forests (Frelich et al., 2006). 
87 abundance of non-native earthworms in the BWCA, we examined lake islands that either had or

88 did not have campsites and were either burned or not burned by the Pagami Creek Fire of 2011.

89 Earthworm abundance was measured in terms of earthworm density, biomass and species

90 richness. We studied islands because they constitute discrete forest patches separated by water

91 that could be characterized as having one condition or the other for each variable (i.e., campsites

92 present/absent, burned/not burned). The islands sampled were located along a chain of

93 interconnected lakes that bordered the northern edge of the 2011 Pagami Creek Fire (Fig. 1).

94 Canoe access for this lake chain is largely limited to a single entry point on Lake One at the west 95 end of the chain. This isolated entry allowed us to examine how distance from the source pool 96 i.e., arriving anglers carrying earthworm bait - affected earthworm abundance across the islands 97 examined.

We hypothesized that islands with campsites would have more earthworms than those

99 without because campsites would receive multiple earthworm introductions from anglers

100 dumping unused bait in or near the campsite (Novo et al., 2015). By contrast, islands that were

101 burned would have fewer earthworms than those not burned because decreased duff and litter on

102 the forest floor, reduced soil organic matter, and decreased leaf litter inputs from trees and

103 vegetation would decrease food availability, thereby limiting earthworm growth and fecundity.

104 Islands having the greatest number of earthworms, therefore, would be those that had campsites

105 and were not burned, whereas those having the least would be burned and without campsites. We

106 also hypothesized that earthworm density and biomass would decrease as distance from the entry

107 point increased. We assumed campsites closest to the entry point would have higher visitation

108 rates because day and weekend anglers would be less likely to travel far into the wilderness 
109 (Lime, 1971). Hypotheses about relationships between variables and earthworm biomass are

110 summarized in Fig. 2.

111

112 Field-Site Description

The $4410 \mathrm{~km}^{2}$ BWCA Wilderness is located in Minnesota's Superior National Forest

$114\left(47^{\circ} 57^{\prime} \mathrm{N}, 91^{\circ} 48^{\prime} \mathrm{W}\right)$ and extends $185 \mathrm{~km}$ along the Minnesota/Ontario border (Fig. 1, inset).

115 Designated as a wilderness area in 1978, the area contains approximately 1175 glacial lakes and

116 hundreds of kilometers of rivers and streams (Heinselman, 1999). It is the largest Forest Service

117 Wilderness area east of the Rocky Mountains and the most heavily used wilderness in the United

118 States, with over 150,000 overnight and day-use visitors annually (Eagleston \& Marion, 2017a).

119 Lakes and waterways comprise approximately $20 \%$ of the BWCAW and cross-country canoe

120 travel is made possible by a network of portage trails that connect lakes. Forests in the BWCA

121 are a mixture of conifers and hardwoods that include various species of pine (Pinus banksiana,

122 P. resinosa, and P. strobus), white cedar (Thuja occidentalis), balsam fir (Abies basamea), white

123 spruce (Picea glauca), and hardwoods such as paper birch (Betula papyrifera), big-toothed aspen

124 (Populus grandidentata) and white oak (Quercus alba) (Dickens, Gerhardt \& Collinge, 2005)

125 The climate of the BWCA region is hemiboreal with mild/cool summers and long winters

126 (Köppen classification Dfb). Average July and January temperatures are $20^{\circ}$ and $-11^{\circ} \mathrm{C}$,

127 respectively, with temperature extremes of $32^{\circ}$ and $-40^{\circ} \mathrm{C}$ occurring (Dickens et al., 2005).

128 Annual precipitation ranges $66-78 \mathrm{~cm}$ and approximately $40 \%$ of this occurs in as snow winter.

129 Soils of the area are thin and acidic and overlay Canadian Shield bedrock. Charcoal is almost

130 universal in upper soil layers, indicative of the key role fire has played in shaping this ecosystem

131 (Heinselman, 1999).

Peer] reviewing PDF | (2019:03:35898:2:0:NEW 20 Jan 2020) 
133 limits the number of people entering through each wilderness entry point. Visitors can obtain

134 permits from May thru September and group sizes are limited to nine. Camping is restricted to

135 approximately 2000 designated campsites established by the by U.S. Forest Service, that are

136 unambiguously indicated by cast iron fire grates located at each site (Eagleston \& Marion, 137 2017b).

\section{Material \& Methods}

On 9 July 2016 we put in canoes at BWCA entry point 30 on Lake One and headed east

141 along a route that skirted the northern edge of the 2011 Pagami Creek Fire (Fig. 1). Over $7 \mathrm{~d}$ we

142 sampled 38 islands (Boundary Waters Canoe Area Wilderness permit \#6-2861367) on lakes

143 One, Two, Three, Four, Hudson and Insula. Islands were selected on the basis of their fire

144 history (burned/not burned) and the presence/absence of campsites (Table 1). Island selection

145 was made using maps showing campsite locations (Fisher map F4) and the area covered by the

146 Pagami Creek Fire (USDA Pagami Creek Fire Map). Initial selection followed a balanced design

147 for each combination of characteristics (i.e., burned/campsite, burned/no campsite, not

148 burned/campsite, not burned/no campsite). However, field sampling revealed islands marked as

149 burned were not, and some campsites on burned islands could not be found. Consequently, these

150 islands were discarded from our sample set and resulted in an unbalanced design.

151 Distances between islands and the entry point were examined using straight-line

152 distances instead of hypothetical canoe travel distances because the latter can be highly variable.

153 Canoeists and anglers need not follow direct pathways between lakes and islands, and side trips 
154 to explore fishing spots and campsite locations are common. Also, multiple pathways may exist

155 for reaching islands, especially in geographically complex lakes such as Insula. Thus,

156 determining actual travel routes becomes a problematic exercise whereas straight-line distances

157 are easily made and independent of human choice.

158 Sampling islands followed a standard procedure: Upon reaching an island, its burn

159 condition, campsite status and GPS coordinates were recorded. Following this, three sampling

160 sites spaced equidistantly around the island's perimeter and approximately $10 \mathrm{~m}$ inland were

161 chosen using three criteria: 1) site accessibility from shore, 2) availability of flat and open

162 ground, and 3) lack of dense underbrush allowing easy access to the ground for sampling. After

163 reaching a site, a center point was established and the percent of understory vegetation cover and

164 percent of exposed soil was estimated within a $1 \mathrm{~m}$ radius of the site center. Visual estimates of

165 cover and exposure were made with the aid of a chart depicting the Braun-Blanquet percent

166 cover classes. Percent exposed soil was converted into percent groundcover by subtracting

167 values from 100. To assess soil organic matter, three soil cores were collected within the

168 established $1 \mathrm{~m}$ radius. The upper $10 \mathrm{~cm}$ of each $2.5 \mathrm{~cm}$ diameter core was collected and

169 combined in a plastic bag for later organic matter analysis in the lab.

water solution was prepared by combining $240 \mathrm{ml}$ of powdered mustard with $4 \mathrm{~L}$ of water. This

solution acts as an irritant that when poured on the ground and allowed to soak into the soil

causes earthworms to emerge as they attempt to avoid the mustard. Half of this mustard solution was poured inside a $0.2 \mathrm{~m}^{2}$ quadrat placed at the site's center and emerging earthworms were collected with forceps and placed in $50 \mathrm{ml}$ plastic centrifuge tubes. After 2 minutes, the

176 remaining solution was poured into the quadrat and earthworms were collected until they 
177 stopped emerging. This procedure was repeated at each site and earthworms from all three sites

178 were combined for each island and preserved in a solution of $70 \%$ isopropyl alcohol and $2 \%$

179 formalin. Field conditions made it impractical to clear earthworm guts prior to preservation.

180 Back in the laboratory, earthworms were identified using Hale (2013) and counted. Worms from

181 each site were then combined, dried and weighed to determine biomass.

182 We used the loss-on-ignition method to determined soil organic matter. Soil was dried in 183 an oven at $40^{\circ} \mathrm{C}$ for 7 days, then homogenized with mortar and pestle. Homogenized samples

184 were put into pre-weighed porcelain crucibles and weighed, then ignited in a muffle-furnace

185 (Fisher Scientific Isotemp Muffle Furnace Model 550-126) at 550 $\mathrm{C}$ for $3 \mathrm{~h}$. The samples were

186 subsequently cooled, placed in a desiccator overnight, and then weighed to the nearest $0.001 \mathrm{~g}$ so

187 biomass could be calculated.

188

189

Statistical analyses

190

Structural Equation Modelling (SEM) was used to us examine relationships between

191 earthworm biomass and the variables included in the metamodel (Fig. 2). To examine the effect

192 of campsite presence, fire history and entry point distance on earthworm richness, density and

193 biomass, we used General Linear Models (GLM).

The SEM was created in AMOS 16 (Amos Development Corporation, 2007) and used to examine direct and indirect relationships between earthworm biomass and fire history, entry

196 point distance, understory plant cover, groundcover, and soil organic matter. We used four

197 indices to assess the fit of the SEM to avoid bias from any one index (Hintz \& Lonzarich, 2018).

198 A chi-square test evaluated the consistency of the data with p-values greater than 0.05 specifying 
199 good fit (Grace et al., 2010). To evaluate model fit we looked at the goodness-of-fit index (GFI),

200 standardized root mean square residual (SRMR), and root mean square error of approximation

201 (RMSEA). GFI values greater than 0.90 and SRMR and RMSEA values below 0.08 indicate

202 good fit (Hooper, Couglan \& Mullen, 2008; Hu \& Bentler, 1999).

203

In order to investigate a possible lack of independence among samples collected from the

204 same lake, we calculated the residuals from the SEM and compared them across lakes. The

205 resulting boxplot showed no evidence of patterns across the lakes. We also plotted a

206 semivariogram of the residuals to assess possible spatial autocorrelation, and no evidence for this

207 this was found either. Thus, samples from the same lake were treated as independent of one

208 another.

209 GLMs were performed using JMP 8.0.1 (SAS Institute Inc., 2009). Models used a

210 Poisson distribution to fit variables and a log link function to create linear models. Chi-squared

$211\left(X^{2}\right)$ probabilities ascertained significance levels of individual factors and interactions. We

212 started with a full model that included main factor effects and all interactions, but found that

213 three-way interactions were not significant so discarded them from the final models. We did not

214 use a nested design (i.e., islands nested within lakes) because the SEM residual analysis showed

215 no lake effect.

216

217 Results

We sampled 38 islands across the six connecting lakes, of these, 12 were burned and 13

219 had campsites (Fig. 1, Table 1). Island size ranged from 0.4 to 11.8 ha and straight-line distances 220 from the entry point ranged between 3.4 and $26.3 \mathrm{~km}$. Earthworms occurred on all but two of the 
221 sampled islands. Mean ( $\pm 1 \mathrm{SE})$ earthworm biomass and density across islands was $12.2 \pm 2.5 \mathrm{~g}$

$222 \mathrm{~m}^{-2}$ and $27.2 \pm 3.5$ individuals $\mathrm{m}^{-2}$, respectively.

Eight earthworm species were identified (Table 2), of which Dendrobaena octaedra

224 (Savigny 1826) and Lumbricus rubellus (Hoffmeister 1843) were most common. Species

225 richness on islands averaged 1.95 species. Juvenile Lumbricus spp. were the most frequently

226 encountered taxonomic group and many of these juveniles were likely L. terrestris (Linnaeus

227 1758); however, their developmental stage precluded positive identification. Campsite presence

228 was the sole factor affecting earthworm species richness $\left(X^{2}=4.13, \mathrm{df}=1,37 ; \mathrm{p}=0.04\right)$, with

229 campsite-bearing islands averaging 1.13 more species than those without.

Campsite presence and burn history had important effects on earthworm abundance.

231 Campsite presence was the only factor that affected both earthworm biomass and density (Table

232 3). The effect on biomass was greater, with campsite-bearing islands having $81 \%$ more

233 earthworm biomass as compared to islands lacking campsites. By comparison, earthworm

234 density on campsite-bearing islands increased by only $37 \%$. Fire was associated with reductions

235 in earthworm density, but not biomass (Table 3, Fig. 3). Earthworm density also responded to a

236 Burned*Campsite interaction such that burned, campsite-bearing islands had approximately half

237 the density of non-burned, campsite-bearing islands (Fig. 3A). Islands without campsites had

238 comparable earthworm densities regardless of burn history.

239 Distance from the entry point directly influenced earthworm density and had interactive

240 effects with campsite presence and burn history on earthworm biomass (Table 3, Fig. 4). Across

241 islands, earthworm density showed a significant decrease as entry point distance increased. By

242 contrast, earthworm biomass increased with entry point distance for campsite-bearing islands

243 while remaining unchanged for islands without campsites (i.e., the Campsite*Distance 
244 interaction shown in Fig. 4A). There was also a Distance*Burned interaction such that

245 earthworm biomass decreased as distance from the entry point increased on burned islands,

246 whereas non-burned islands showed the opposite trend (Fig. 4B).

Our SEM (Fig. 5) showed a good fit to the data with a high GFI (0.96), low SRMR (0.08) and RMSEA (0.00), and a non-significant chi-square $\left(X^{2}=6.32, \mathrm{df}=9, \mathrm{p}=0.71\right)$. Overall, the model explained $47 \%$ of the variation in earthworm biomass found on BWCA islands.

SEM analysis broadly corroborated the results of the GLM in that both models showed that campsite presence was the most important single factor affecting earthworm biomass. The SEM showed that entry point distance had a direct and positive relationship with earthworm biomass whereas fire exerted its influence through other factors. Fire was associated with less groundcover and soil organic matter, but more understory plant cover. Of these three factors, only groundcover affected earthworm biomass. Groundcover had a positive relationship to earthworm biomass whereas soil organic matter and understory plant cover showed none. Understory plant cover was also positively correlated to earthworm biomass.

\section{Discussion}

We hypothesized that earthworms would be more abundant on islands with campsites, less abundant on those that had burned, and would decrease as distance from the entry point

262 increased. Our data provide strong support for the first hypothesis (campsites), partial support for 263 the second (burn history), and little support for the third (entry point distance). 
266 findings of previous studies showing that human activity influences the distribution and

267 abundance of non-native earthworms (Hendrix et al., 2008; Shartell et al. 2015). These include

268 correlations with road proximity (Cameron \& Bayne, 2009) and boat launches (Cameron, Bayne

269 \& Clapperton, 2007), and their spread through use as fish bait (Keller et al., 2007). That

270 wilderness campsites may be important points of invasion for non-native species is often

271 overlooked in studies of campsite impacts (e.g., Monz, Pickering \& Hadwen, 2013; Eagleston \&

272 Marion, 2017b; Marion et al., 2016), despite the fact that campsites are where people leave

273 behind food wastes (a potential source of seeds), and may inadvertently transport seeds and other

274 propagules on clothing, footwear or camping equipment (Ansong \& Pickering, 2013; Eagleston

$275 \&$ Marion, 2017a). Campsites might be construed, therefore, as nodes in a distribution network

276 facilitating the spread of exotic species across wilderness areas. This may be especially true in

277 the BWCA because nearly all travel is done by canoe, which makes established campsites and

278 canoe portages (Dickens et al., 2005) the main points of contact between visitors and the

279 wilderness landscape.

280 Fire effects were not as prominent as campsite effects. Although burned islands did have

281 lower densities of earthworms as predicted, earthworm biomass and richness were unaffected.

282 Fires can kill epigeic species that live in the litter (Ikeda et al., 2015), but are less likely to affect

283 endogenic and anecic species that burrow into the soil. Fire increases soil temperatures just a few

284 degrees $5 \mathrm{~cm}$ below the surface (Ikeda et al., 2015), and some earthworms could easily burrow

285 deeper to avoid excessive heat." Rather than killing worms directly, we expected fire to exert

286 influence through its effects on ground cover, soil organic matter, and understory vegetation,

287 decreasing the former two and increasing the latter. Our SEM showed that fire had the predicted 
288 effects on these three variables, but only groundcover had a significant effect on earthworm

289 biomass such that, where litter was abundant, so was earthworm biomass.

291 studies have shown that earthworms invading northern forests typically cause understory

292 vegetation to decline (see Bohlen et al., 2004b for review). Earthworms can consume newly

293 germinated seedlings (Drouin et al., 2014), the fine roots of plants (Gilbert et al., 2014), and alter

294 the soil microflora to favor only certain species (Drouin, Bradley \& Lapointe, 2016). Of course,

295 earthworms can have beneficial effects, as is seen in horticultural and agricultural systems

296 (Bertrand et al., 2015; Sharma, Tomar \& Chakraborty, 2017), but why these benefits would

297 occur on islands and not in other areas of the BWCA is outside the scope of our study.

298 The most perplexing result of our study was the positive relationship between entry point

299 distance and earthworm biomass. Our prediction was that earthworm biomass would decrease on

300 islands further away from the entry point, and this was based on the assumption that discarding

301 unused earthworm bait would be more frequent in areas of high human traffic closer to the entry

302 point. We reasoned that weekend anglers do not travel far from entry points and bait dumping

303 would become less frequent further away as angler traffic diminished. Of course, our

304 assumptions about human behavior may be wrong. We speculate that anglers may actually be

305 less likely to dispose of worms if they are fishing for only short time. In a survey of Wisconsin

306 and Michigan boat owners, Keller et al. (2007) reported that $65 \%$ of anglers saved leftover

307 earthworm bait for future fishing trips as opposed to $41 \%$ who disposed of them on land or in

308 trash. Similar results were found by Kilian et al. (2012) in their survey of Maryland anglers.

309 Earthworms are sold in soil-packed containers and can be kept alive for weeks under cool and

310 moist conditions (Sherman, 2003). If bait containers are exposed to long days in a sunlit canoe, 
311 however, their viability may be compromised. Desiccating soil and temperatures exceeding $30^{\circ}$

312 C can kill earthworms (Berry \& Jordan, 2001), and we speculate that multi-day canoe trips are

313 likely to have higher bait mortality than day or weekend trips. Rather than pack out dead and

314 dying worms, long-distance anglers may choose to dump bait containers enroute as they pass

315 through the wilderness. Even if adult earthworms in containers are dead, the soil in which they

316 were kept could contain earthworm cocoons. Whether or not this practice actually occurs would

317 require further study, yet it highlights the need for understanding human behavior for managing

318 the spread of earthworms in the BWCA (Eagleston \& Marion, 2017a; 2017b; Marion et al., 319 2016).

320

321 Conclusion

322

Earthworms are often called ecosystem engineers because of the multitudinous effects

323 they have on soils, nutrient cycling, and plants and animals (Holdsworth, Frelich \& Reich, 2007;

324 Eisenhauer, 2010). Their presence can profoundly alter ecosystems and their invasion into

325 wilderness areas presents a challenge for resource managers charged with maintaining these

326 natural systems in a state similar to what they were pre-European settlement (Blouin et al.,

327 2013). Our investigation of how campsites, fire, and entry point proximity influence earthworm

328 abundance in the BWCA has management implications. Our data support the hypothesis that

329 campsites are key points of invasion, and suggest that fire may lower earthworm densities via its

330 influence on worm food resources (e.g., litter and duff). Our data also indicate that the distance

331 from a wilderness entry point can influence the distribution and abundance of invasive worms,

332 and these effects may be best understood in the context of campsite use behaviors and bait use

333 practices. We recommend that resource managers promote "leave no trace" principles that 
334 emphasize the environmental risks posed by invasive species; for example, by incorporating this

335 message in videos visitors are required to watch before entering the BWCA (Guo et al., 2017).

336 As part of their public education efforts, managers might also consider bait container warning

337 labels that include instructions on the proper earthworm disposal after use. These actions may

338 slow the spread of earthworms in the BWCA and other wilderness areas, although removing

339 these ecosystem engineers from invaded regions is problematic at best, if not impossible. Once

340 introduced, earthworms become part of the ecosystem (Bohlen et al., 2004b), and efforts directed

341 at learning ways to mitigate their impacts will likely become as important as trying to control

342 their spread (Tammeorg et al., 2014).

\section{Acknowledgements}

345 We wish to thank Wil Raasch for his contributions to the work, and David Lonzarich for his 346 assistance with the SEM analysis.

Ansong, M., and C. Pickering. 2013. Long-distance dispersal of Black Spear Grass Park. Ecological Management and Restoration 14(1):1-4.

Berry, E. C., and D. Jordan. 2001. Temperature and soil moisture content effects on the growth of Lumbricus terrestris (Oligochaeta: Lumbricidae) under laboratory conditions. Soil 
358

359

360

361

362

363

364

365

366

367

368

369

370

371

372

373

374

375

376

377

378

Blouin, M., M. E. Hodson, E. A. Delgado, G. Baker, L. Brussaard, K. R. Butt, J. Dai, L. Dendooven, G. Peres, J. E. Tondoh, D. Cluzeau, and J. J. Brun. 2013. A review of earthworm impact on soil function and ecosystem services. European Journal of Soil Science 64:161-182.

Bohlen, P. J., P. M. Groffman, T. J. Fahey, M. C. Fisk, E. Suarez, D. M. Pelletier, and R. T. Fahey. 2004a. Ecosystem consequences of exotic earthworm invasion of north temperate forests. Ecosystems 7:1-12.

Bohlen, P. J., S. Scheu, C. M. Hale, M. A. McLean, S. Migge, P. M. Groffman, and D. Parkinson. 2004b. Non-native invasive earthworms as agents of change in northern temperate forests. Frontiers in Ecology and the Environment 2:427-435.

Callaham, M. A., and J. M. Blair. 1999. Influence of differing land management on the invasion of North American tallgrass prairie soils by European earthworms. Pedobiologia 43:507512.

Callaham, M. A., J. M. Blair, T. C. Todd, D. J. Kitchen, and M. R. Whiles. 2003. Macroinvertebrates in North American tallgrass prairie soils: effects of fire, mowing, and fertilization on density and biomass. Soil Biology \& Biochemistry 35:1079-1093.

Callaham, M. A., G. Gonzalez, C. M. Hale, L. Heneghan, S. L. Lachnicht, and X. M. Zou. 2006. Policy and management responses to earthworm invasions in North America. Biological Invasions 8:1317-1329.

Cameron, E. K., and E. M. Bayne. 2009. Road age and its importance in earthworm invasion of northern boreal forests. Journal of Applied Ecology 46:28-36. 
379 Cameron, E. K., E. M. Bayne, and M. J. Clapperton. 2007. Human-facilitated invasion of exotic 380 earthworms into northern boreal forests. Ecoscience 14:482-490.

381 Costello, D. M., and G. A. Lamberti. 2009. Biological and physical effects of non-native 382 383 earthworms on nitrogen cycling in riparian soils. Soil Biology \& Biochemistry 41:2230-

Coyle, D. R., U. J. Nagendra, M. K. Taylor, J. H. Campbell, C. E. Cunard, A. H. Joslin, A. 385 Mundepi, C. A. Phillips, and M. A. Callaham. 2017. Soil fauna responses to natural disturbances, invasive species, and global climate change: Current state of the science and a call to action. Soil Biology \& Biochemistry 110:116-133.

Dickens, S. J. M., F. Gerhardt, and S. K. Collinge. 2005. Recreational portage trails as corridors facilitating non-native plant invasions of the Boundary Waters Canoe Area Wilderness (U.S.A.). Conservation Biology 19:1653-1657.

Dobson, A., and B. Blossey. 2015. Earthworm invasion, white-tailed deer and seedling establishment in deciduous forests of north-eastern North America. Journal of Ecology 103:153-164.

Drouin, M. 1., R. Bradley, and L. Lapointe. 2016. Linkage between exotic earthworms, understory vegetation and soil properties in sugar maple forests. Forest Ecology and Management 364:113-121.

Drouin, M., R. Bradley, L. Lapointe, and J. Whalen. 2014. Non-native anecic earthworms (Lumbricus terrestris L.) reduce seed germination and seedling survival of temperate and boreal trees species. Applied Soil Ecology 75:145-149. 
401

402

403

404

405

406

407

408

409

410

411

412

413

414

415

416

417

418

419

420

421

422

changes in non-native plant dynamics on campsites, Boundary Waters, Minnesota. Forest Science 64(1): 50-56.

Eagleston, H., and J. L. Marion. 2017b. Sustainable campsite management in protected areas: A study of long-term ecological changes on campsites in the Boundary Waters Canoe Area Wilderness, Minnesota, USA. Journal for Nature Conservation 37:73-82.

Eisenhauer, N. 2010. The action of an animal ecosystem engineer: Identification of the main mechanisms of earthworm impacts on soil microarthropods. Pedobiologia 53:343-352.

Frelich, L. E., C. M. Hale, S. Scheu, A. R. Holdsworth, L. Heneghan, P. J. Bohlen, and P. B. Reich. 2006. Earthworm invasion into previously earthworm-free temperate and boreal forests. Biological Invasions 8:1235-1245.

Frelich, L. E., and P. B. Reich. 2009. Wilderness conservation in an era of global warming and invasive species: a case study from Minnesota's Boundary Waters Canoe Area Wilderness. Natural Areas Journal 29:385-393.

Fisichelli, N. A., L. E. Frelich, P. B. Reich, and N. Eisenhauer. 2013. Linking direct and indirect pathways mediating earthworms, deer, and understory composition in Great Lakes forests. Biological Invasions 15:1057-1066.

Gilbert, K. J., T. J. Fahey, J. C. Maerz, R. E. Sherman, P. Bohlen, J. J. Dombroskie, P. M. Groffman, and J. B. Yavitt. 2014. Exploring carbon flow through the root channel in a temperate forest soil food web. Soil Biology and Biochemistry 76:45-52.

Grace, J. B., T. M. Anderson, H. Olff, and S. M. Scheiner. 2010. On the specification of structural equation models for ecological systems. Ecological Monographs 80:67-87.

Guo, T., J. W. Smith, R. L. Moore, and C. L. Schultz. 2017. Integrating off-site visitor education 
423

424

425

426

427

428

429

430

431

432

433

434

435

436

437

438

439

440

441

442

443

444

into landscape conservation and management: An examination of timing of educational messaging and compliance with low-impact hiking recommendations. Landscape and Urban Planning 164:25-36.

Hale, C. M. 2008. Evidence for human-mediated dispersal of exotic earthworms: support for exploring strategies to limit further spread. Molecular Ecology 17:1165-1169.

Hale, C. M. 2013. Earthworms of the Great Lakes, Second edition edition. Kollath-Stensaas Publishing, Duluth, MN. 52 pp.

Hale, C. M., L. E. Frelich, and P. B. Reich. 2005. Exotic European earthworm invasion dynamics in northern hardwood forests of Minnesota, USA. Ecosystems 15:848-860.

Hale, C. M., L. E. Frelich, P. B. Reich, and J. Pastor. 2008. Exotic earthworm effects on hardwood forest floor, nutrient availability and native plants: a mesocosm study. Oecologia 155:509-518.

Heinselman, M. 1999. The Boundary Waters Wilderness Ecosystem. University of Minnesota Press. $352 \mathrm{pp}$.

Hendrix, P. F., M. A. Callaham, J. M. Drake, C.-Y. Huang, S. W. James, B. A. Snyder, and W. Zhang. 2008. Pandora's box contained bait: The global problem of introduced earthworms. The Annual Review of Ecology, Evolution and Systematics 39:593-613.

Hintz, W. D., and D. G. Lonzarich. 2018. Maximizing foraging success: the roles of group size, predation risk, competition, and ontogeny. Ecosphere 9(10): e02456.10.1002/ecs2.2456.

Holdsworth, A. R., L. E. Frelich, and P. B. Reich. 2007. Regional extent of an ecosystem engineer: Earthworm invasion in northern hardwood forests. Ecological Applications $17: 1666-1677$.

Peer] reviewing PDF | (2019:03:35898:2:0:NEW 20 Jan 2020) 
445 Hooper, D., J. C. Couglan, and M. R. Mullen. 2008. Structural equation modelling: guidelines 446 for determining model fit. Electronic Journal of Business Research Methods 6:53-60.

447 Hopfensperger, K. N., and S. Hamilton. 2015 Earthworm communities in previously glaciated 448 and unglaciated eastern deciduous forests. Southeastern Naturalist 14:66-84.

449 Hopfensperger, K. N., G. M. Leighton, and T. J. Fahey. 2011. Influence of invasive earthworms 450 on above and belowground vegetation in a northern hardwood forest. The American Midland Naturalist 166:53-62.

Hu, L., and P. M. Bentler. 1999. Cutoff criteria for fit indexes in covariance structure analysis: conven- tional criteria versus new alternatives. Structural Equation Modeling 6:1-55.

454 Ikeda, H., M. A. Callaham, J. J. O'Brien, B. S. Hornsby, and E. S. Wenk. 2015. Can the invasive 455 earthworm, Amynthas agrestis, be controlled with prescribed fire? Soil Biology \& Biochemistry 82:21-27.

James, S. W. 1982. Effects of fire and soil type on earthworm populations in a tallgrass prairie. Pedobiologia 24:37-40.

James, S. W. 1988. The postfire environment and earthworm populations in tallgrass prairie. Ecology 69(2): 476-483.

Keller, R. P., A. N. Cox, C. Van Loon, D. M. Lodge, L.-M. Herborg, and J. Rothlisberger. 2007. From shops to the forest floor: earthworm use and disposal by anglers. The American Midland Naturalist 158:321-328. species. Biological Invasions 14:1469-1481. 
467 Lime, D. W. 1971. Factors influencing campground use in the Superior National Forest of 468 Minnesota. Research Paper NC-60. St. Paul, MN: U.S. Dept. of Agriculture, Forest 469 Service, North Central Forest Experiment Station.

470 Loss, S. R., and R. B. Blair. 2011. Reduced density and nest survival of ground-nesting 471 472 songbirds relative to earthworm invasions in northern hardwood forests. Conservation Biology 25:983-992.

473

474

475

476
Marion, J. L., L. Yu-Fai, H. Eagleston, and K. Burroughs. 2016. A review and synthesis of recreation ecology research findings on visitor impacts to wilderness and protected natural areas. Journal of Forestry 114: 352-362.

Monz, C. A., C. M. Pickering, and W. L. Hadwen. 2013. Recent advances in recreation ecology and the implications of different relationships between recreation use and ecological impacts. Frontiers in Ecology and the Environment 11:441-446.

Novo, M., L. Cunha, A. Maceda-Veiga, J. A. Talavera, M. E. Hodson, D. Spurgeon, M. W. Bruford, A. J. Morgan, and P. Kille. 2015. Multiple introductions and environmental factors affecting the establishment of invasive species on a volcanic island. Soil Biology \& Biochemistry 85:89-100.

Nuzzo, V., A. Davalos, and B. Blossey. 2015. Invasive earthworms shape forest seed bank composition. Diversity and Distributions 21:560-570.

Sharma, D. K., S. Tomar, and D. Chakraborty. 2017. Role of earthworm in improving soil structure and functioning. Current Science 113:1064-1071.

Shartell, L. M., R. G. Corace, A. J. Storer, and D. M. Kashian. 2015. Broad and local-scale patterns of exotic earthworm functional groups in forests of National Wildlife Refuges of 
the Upper Midwest, USA. Biological Invasions 17:3591-3607.

490 Sherman, R. 2003. Raising Earthworms Successfully. North Carolina Cooperative Extension 491 Service Publication \# EBAE 103-83, North Carolina State University, Raleigh, NC. 26

$492 \quad$ pp.

493 Tammeorg, P., T. Parviainen, V. Nuutinen, A. Simojoki, E. Vaara, and J. Helenius. 2014. Effects 494 of biochar on earthworms in arable soil: avoidance test and field trial in boreal loamy 495 sand. Agriculture, Ecosystems and Environment 191:150-157.

496 Tiunov, A. V., C. M. Hale, A. R. Holdsworth, and T. S. Vsevolodova-Perel. 2006. Invasion 497 patterns of Lumbricidae into the previously earthworm-free areas of northeastern Europe 498 and the western Great Lakes region of North America. Biological Invasions 8:1223-1234. 


\section{Table $\mathbf{1}$ (on next page)}

Physical characteristics of the 38 sampled islands.

"X"s indicate that islands were burned by the Pagami Creek Fire or had a campsite. Entry distance is the linear distance from BWCA entry point 30 on Lake One (see Fig. 1), Island Size is the area of the island. 
Table 1.

2

\begin{tabular}{|c|c|c|c|c|c|c|c|}
\hline Island \# & Latitude & Longitude & Lake & Burned & Campsite & $\begin{array}{c}\text { Entry Distance } \\
(\mathbf{k m})\end{array}$ & $\begin{array}{c}\text { Island Size } \\
\text { (ha) }\end{array}$ \\
\hline 1 & N 4755.45 & W 9129.10 & One & - & $\mathrm{X}$ & 3.4 & 3.85 \\
\hline 2 & N 4755.31 & W 9129.19 & One & - & - & 3.7 & 4.72 \\
\hline 3 & N 4755.17 & W 9129.68 & One & - & - & 4.1 & 2.89 \\
\hline 4 & N 4755.27 & W 9129.56 & One & - & $\mathrm{X}$ & 4.2 & 0.94 \\
\hline 5 & N 4755.03 & W 9129.21 & One & - & - & 4.3 & 0.52 \\
\hline 6 & N 4754.90 & W 9129.62 & One & - & - & 4.4 & 2.12 \\
\hline 7 & N 4755.20 & W 9129.71 & One & - & - & 4.5 & 2.16 \\
\hline 8 & N 4755.03 & W 9128.99 & One & - & - & 4.5 & 0.72 \\
\hline 9 & N 4755.03 & W 9129.21 & One & - & - & 4.8 & 0.83 \\
\hline 10 & N 4754.33 & W 9127.79 & Two & $\mathrm{X}$ & $\mathrm{X}$ & 6.7 & 1.40 \\
\hline 11 & N 4754.43 & W 9127.33 & Two & - & - & 7.0 & 0.60 \\
\hline 12 & N 4753.04 & W 9126.69 & Three & - & - & 7.2 & 0.40 \\
\hline 13 & N 4753.81 & W 9126.60 & Three & - & $\mathrm{X}$ & 8.8 & 2.63 \\
\hline 14 & N 4753.58 & W 9126.73 & Three & - & - & 9.0 & 0.53 \\
\hline 15 & N 4753.70 & W 9126.56 & Three & $\mathrm{X}$ & - & 9.0 & 0.75 \\
\hline 16 & N 4753.42 & W 9127.09 & Three & - & - & 9.1 & 0.65 \\
\hline 17 & N 4753.02 & W 9126.50 & Three & $\mathrm{X}$ & $\mathrm{X}$ & 9.4 & 6.58 \\
\hline 18 & N 4753.04 & W 9126.94 & Three & $\mathrm{X}$ & - & 9.5 & 11.81 \\
\hline 19 & N 4752.98 & W 9127.11 & Three & $\mathrm{X}$ & $\mathrm{X}$ & 10.0 & 9.25 \\
\hline 20 & N 4753.75 & W 9125.85 & Three & - & - & 10.7 & 5.96 \\
\hline 21 & N 4753.01 & W 9126.52 & Three & $\mathrm{X}$ & - & 10.8 & 1.24 \\
\hline 22 & N 4753.12 & W 9126.53 & Three & - & $\mathrm{X}$ & 11.0 & 0.73 \\
\hline 23 & N 4754.00 & W 9123.11 & Four & - & - & 14.0 & 1.74 \\
\hline 24 & N 4753.73 & W 9120.85 & Hudson & $X$ & $\mathrm{X}$ & 17.4 & 1.31 \\
\hline 25 & N 4754.24 & W 9117.02 & Insula & $\mathrm{X}$ & - & 23.0 & 5.02 \\
\hline 26 & N 4754.22 & W 9116.38 & Insula & $X$ & $\mathrm{X}$ & 23.6 & 1.21 \\
\hline 27 & N 4754.56 & W 9116.82 & Insula & - & $X$ & 24.0 & 2.28 \\
\hline 28 & N 4754.55 & W 9117.06 & Insula & $X$ & - & 24.0 & 0.64 \\
\hline 29 & N 4754.62 & W 9117.41 & Insula & $X$ & - & 24.0 & 0.52 \\
\hline 30 & N 4754.70 & W 9117.23 & Insula & - & $\mathrm{X}$ & 24.1 & 4.17 \\
\hline 31 & missing & missing & Insula & - & - & 24.1 & 7.31 \\
\hline 32 & N 4754.71 & W 9117.64 & Insula & $\mathrm{X}$ & - & 24.3 & 1.18 \\
\hline 33 & N 4754.79 & W 9117.77 & Insula & - & - & 24.6 & 0.45 \\
\hline 34 & N 4755.16 & W 9118.05 & Insula & - & - & 25.4 & 0.68 \\
\hline 35 & N 4755.65 & W 9116.80 & Insula & $\mathrm{X}$ & $\mathrm{X}$ & 25.7 & 0.90 \\
\hline 36 & N 4755.65 & W 9117.02 & Insula & - & - & 25.9 & 1.27 \\
\hline 37 & N 4755.79 & W 9117.26 & Insula & - & - & 26.1 & 0.71 \\
\hline 38 & N 4755.93 & W 9117.11 & Insula & - & $\mathrm{X}$ & 26.3 & 1.28 \\
\hline
\end{tabular}




\section{Table 2 (on next page)}

Earthworm species or juvenile genera encountered on sampled islands.

"X"s indicate that islands were burned by the Pagami Creek Fire or had a campsite. 


\begin{tabular}{|c|c|c|c|c|c|c|c|c|c|c|c|c|}
\hline Island \# & Burned & Campsite & 胥 & 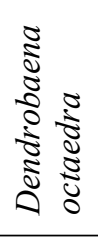 & 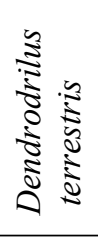 & 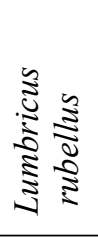 & 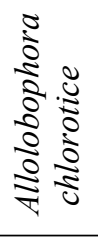 & 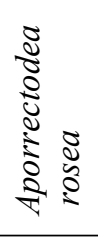 & 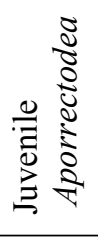 & 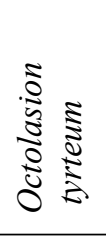 & 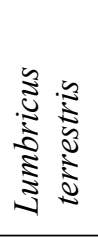 & 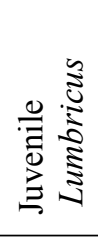 \\
\hline 1 & - & X & 5 & - & - & - & - & - & - & - & - & - \\
\hline 2 & - & - & - & 45 & - & - & - & - & - & - & - & - \\
\hline 3 & - & - & - & - & - & - & - & 5 & - & - & - & 20 \\
\hline 4 & - & $\mathrm{X}$ & - & - & - & - & - & - & - & - & - & 5 \\
\hline 5 & - & - & - & 30 & - & - & - & - & - & - & - & - \\
\hline 6 & - & - & - & 10 & - & - & - & - & - & - & - & - \\
\hline 7 & - & - & - & 30 & - & - & - & - & - & - & - & - \\
\hline 8 & - & - & - & 5 & - & - & - & 5 & - & - & - & 35 \\
\hline 9 & - & - & - & 5 & - & - & - & - & - & - & - & - \\
\hline 10 & $\mathrm{X}$ & $\mathrm{X}$ & - & - & - & - & - & - & 5 & - & - & 20 \\
\hline 11 & - & - & - & 30 & - & - & - & - & - & - & - & - \\
\hline 12 & - & - & 5 & 5 & - & - & - & - & - & - & - & - \\
\hline 13 & - & $\mathrm{X}$ & - & - & - & 30 & - & - & 10 & - & - & 50 \\
\hline 14 & - & - & - & - & - & 15 & - & - & 5 & - & - & 35 \\
\hline 15 & $X$ & - & - & - & - & - & - & - & - & - & 5 & 20 \\
\hline 16 & - & - & - & 10 & - & 5 & - & - & - & - & - & - \\
\hline 17 & $X$ & $\mathrm{X}$ & 10 & 5 & - & - & - & - & - & 5 & 5 & - \\
\hline 18 & $X$ & - & - & - & - & 10 & - & - & - & - & - & 10 \\
\hline 19 & $X$ & $X$ & - & - & - & 5 & - & - & - & - & 5 & 10 \\
\hline 20 & - & - & - & 25 & - & - & - & - & - & - & - & - \\
\hline 21 & $X$ & - & - & - & - & 10 & - & - & - & - & - & 35 \\
\hline 22 & - & $X$ & 40 & 5 & - & - & 5 & - & 5 & 10 & - & 10 \\
\hline 23 & - & - & - & 5 & - & - & - & - & - & - & - & 5 \\
\hline 24 & $X$ & $X$ & - & - & - & - & - & - & - & - & 5 & 10 \\
\hline 25 & $X$ & - & - & - & - & - & - & - & - & - & - & - \\
\hline 26 & $X$ & $X$ & - & - & - & - & - & - & - & - & - & 10 \\
\hline 27 & - & $X$ & - & 5 & - & - & - & - & - & - & 5 & 20 \\
\hline 28 & $X$ & - & - & 10 & - & - & - & - & - & - & - & - \\
\hline 29 & $X$ & - & - & 5 & - & - & - & - & - & - & - & 5 \\
\hline 30 & - & $X$ & - & - & 10 & - & - & 5 & 15 & - & - & 30 \\
\hline 31 & - & - & - & 15 & - & - & - & - & - & - & - & 10 \\
\hline 32 & $X$ & - & - & - & - & - & - & - & - & - & - & 15 \\
\hline 33 & - & - & - & - & - & - & - & - & - & - & - & - \\
\hline 34 & - & - & - & 20 & - & - & - & - & - & - & - & 10 \\
\hline 35 & $X$ & $X$ & - & - & - & - & - & - & 5 & - & 5 & 30 \\
\hline
\end{tabular}

1 Table 2. 


\begin{tabular}{|c|c|c|c|c|c|c|c|c|c|c|c|c|}
\hline 36 & - & - & - & - & - & - & - & 10 & - & - & - & - \\
\hline 37 & - & - & - & - & - & - & - & - & - & - & - & 15 \\
\hline 38 & - & $X$ & - & - & - & 20 & - & - & - & - & 5 & - \\
\hline Totals & & & 60 & 265 & 10 & 95 & 5 & 25 & 45 & 15 & 35 & 410 \\
\hline
\end{tabular}




\section{Table 3 (on next page)}

Effects of campsites, fire and entry point distance on earthworm biomass and density.

Results of the two General Linear Models used to examine earthworm biomass $\left(\mathrm{g} \mathrm{m}^{-2}\right)$ and density (individuals $\mathrm{m}^{-2}$ ) in relation to burn history (Burned), campsite presence (Campsite) and linear distance from the BWCA entry point (Distance), as well as interactions among these factors $(d f=1,36)$. Bold font indicates significant $p$-values. Whole model statistics: $X^{2}$ density $=45.30, d f=6,31, p<0.0001 ; X^{2}$ biomass $=84.23, d f=6,31, p<0.0001$. 
1

2 Table 3.

3

\begin{tabular}{lcccc} 
& \multicolumn{2}{c}{ Biomass } & \multicolumn{2}{c}{ Density } \\
\hline Factor & $\boldsymbol{X}^{\mathbf{2}}$ & P-value & $\boldsymbol{X}^{\mathbf{2}}$ & P-value \\
\hline Burned & 0.67 & 0.413 & 8.51 & $\mathbf{0 . 0 0 4}$ \\
Campsite & 27.82 & $<\mathbf{0 . 0 0 1}$ & 4.92 & $\mathbf{0 . 0 2 7}$ \\
Distance & 0.45 & 0.500 & 17.01 & $<\mathbf{0 . 0 0 1}$ \\
Burned*Campsite & 0.19 & 0.665 & 13.74 & $<\mathbf{0 . 0 0 1}$ \\
Campsite*Distance & 5.32 & $\mathbf{0 . 0 2 1}$ & 1.25 & 0.26 \\
Distance*Burned & 6.41 & $\mathbf{0 . 0 1 1}$ & 2.19 & 0.14 \\
& & & & \\
\end{tabular}

4

5

6 
Figure 1

Study location.

Map shows the location of the Boundary Waters Canoe Area Wilderness in northern

Minnesota (inset) and the study area (small white rectangle), which has been enlarged to show the six connecting lakes (One, Two, Three, Four, Hudson and Insula) and the 38 islands that were sampled (shown in black). The dotted line represents the northern extent of the 2011 Pagami Creek Fire; the area south of the line was burned by the fire.

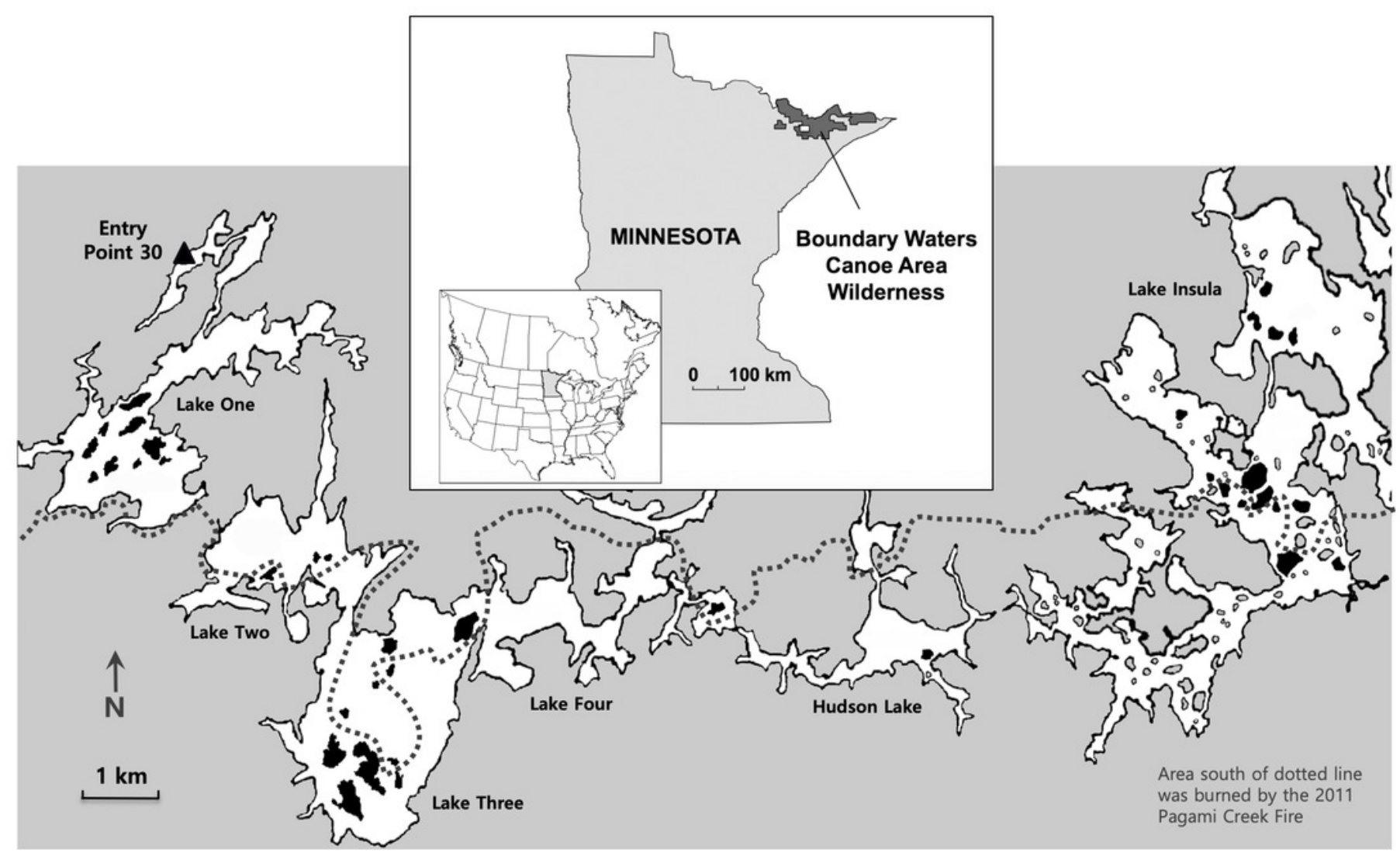


Figure 2

Metamodel depicting hypothesized relationships.

Solid lines show positive relationships; dashed lines show negative relationships.

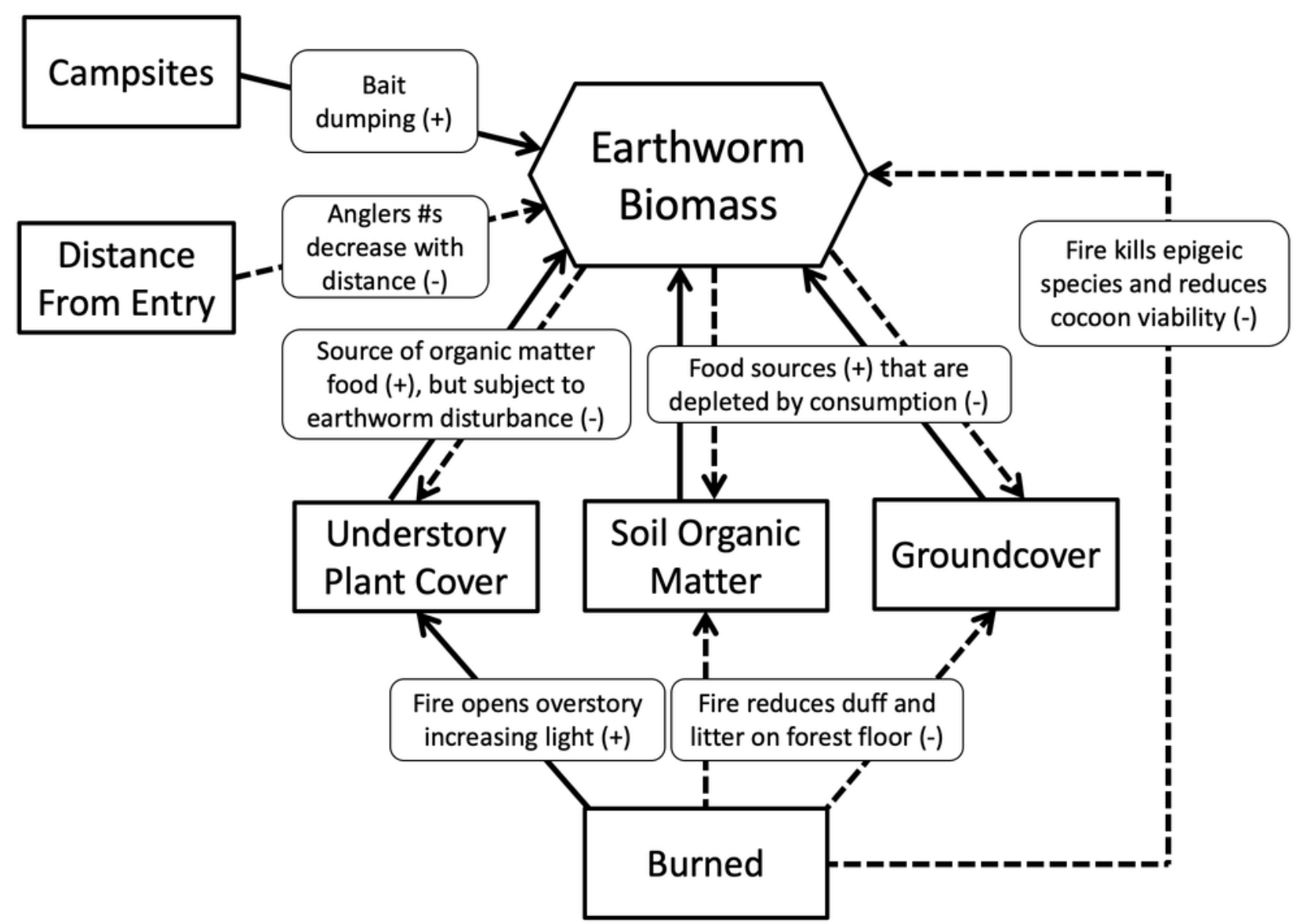


Figure 3

Interactive effects influencing earthworm biomass.

The effect of campsite presence and fire history on earthworm biomass and density. Values are mean ( \pm 1 SEM). GLM analyses indicated a significant campsite*burn interaction for earthworm density (A), but not earthworm biomass (B).

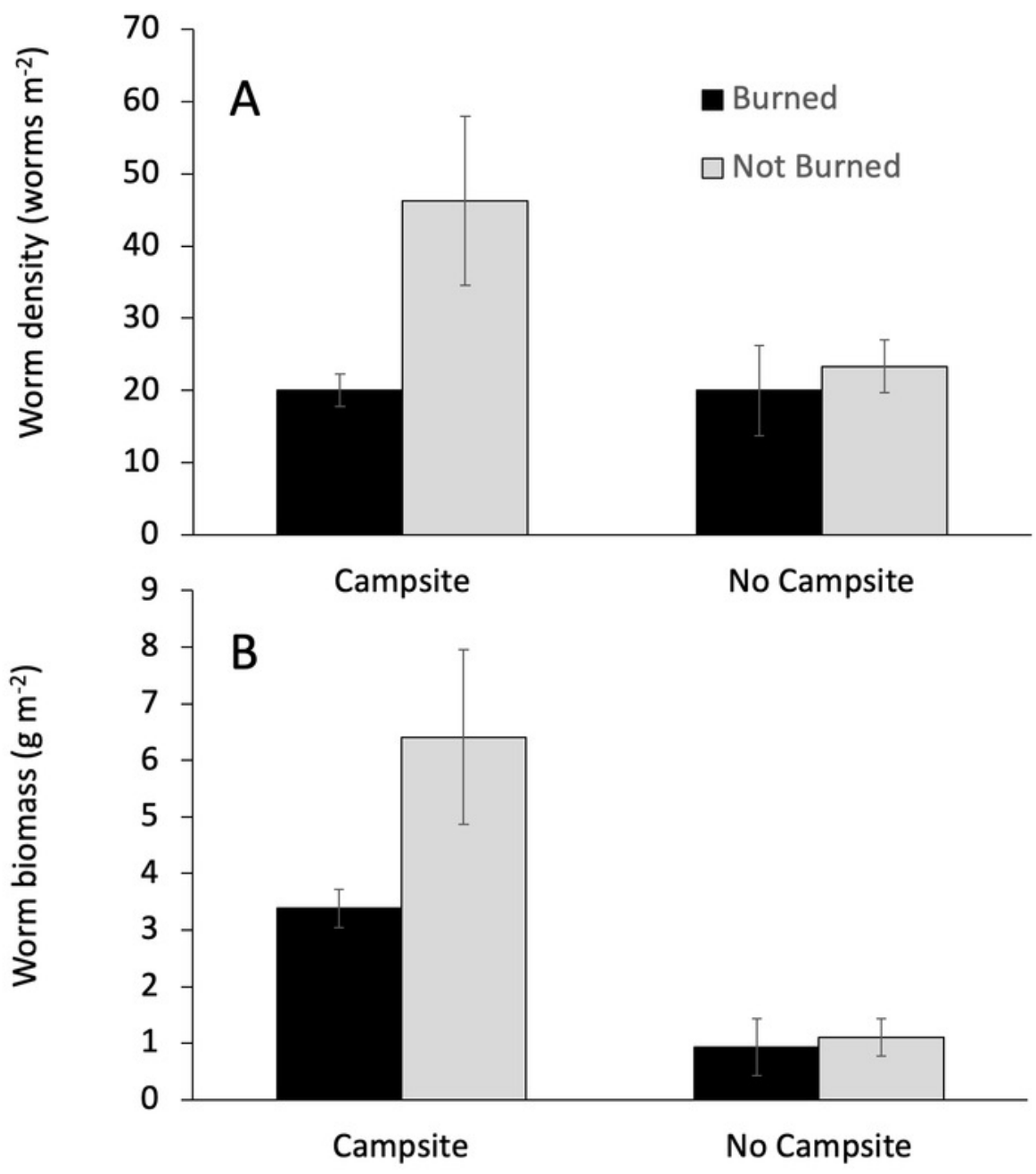


Figure 4

Interactive effects influencing earthworm biomass.

The interaction between entry point distance and burn history (A), and entry point distance and campsite presence (B) on earthworm biomass.
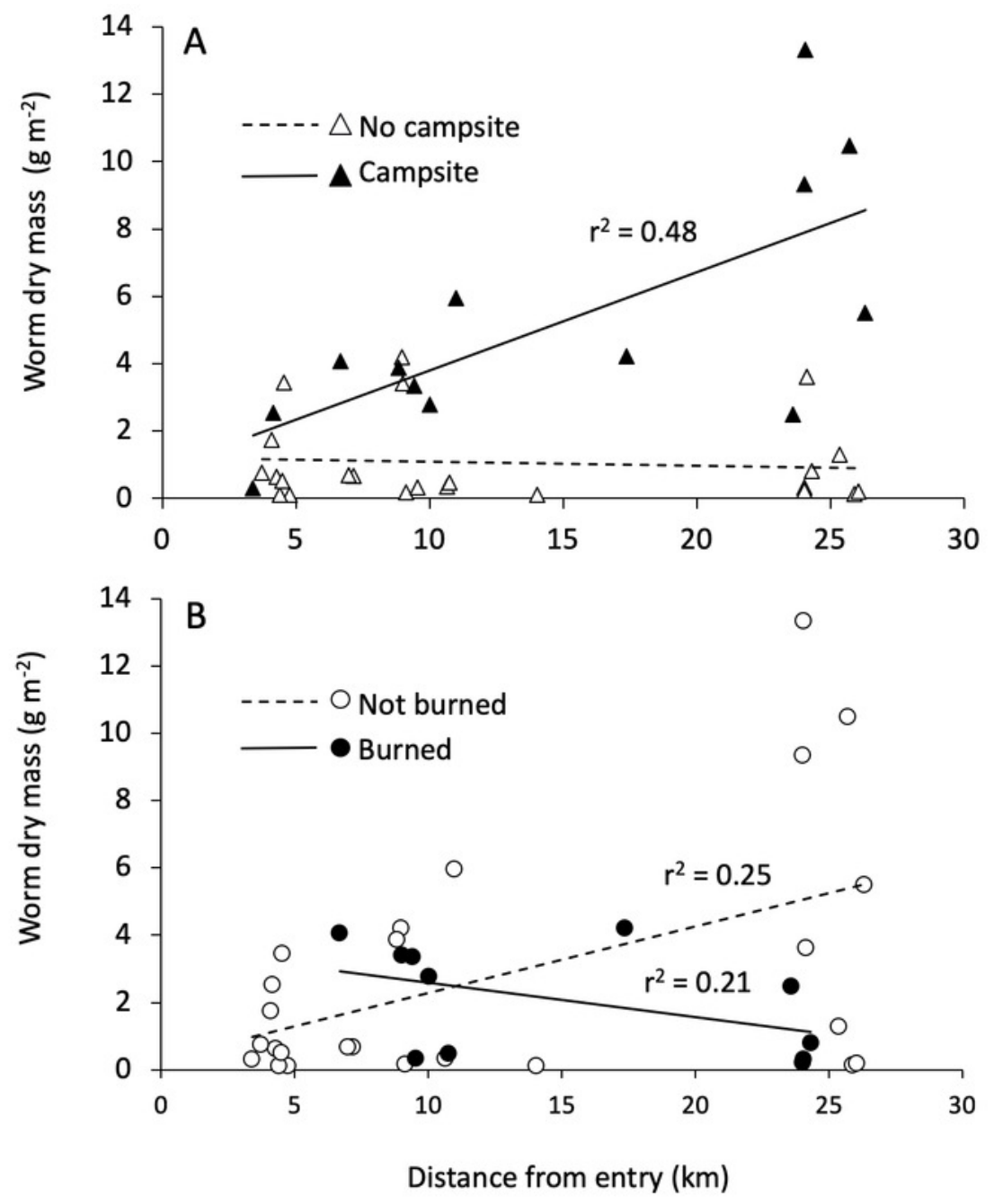
Figure 5

Structural equation model representing the relationships between study variables and earthworm biomass.

Latent variables associated with endogenous factors are not shown. Solid arrows indicate positive effects; dashed arrows indicate negative effects. Dotted grey arrows labeled "ns" indicated non-significant relationships $(P>0.10)$. Model parameters are as follows: chi-square $=6.32, \mathrm{df}=9, \mathrm{p}=0.71 ; \mathrm{GFI}=0.96 ; \mathrm{RMSEA}=0.00 ; \mathrm{SRMR}=0.081$.

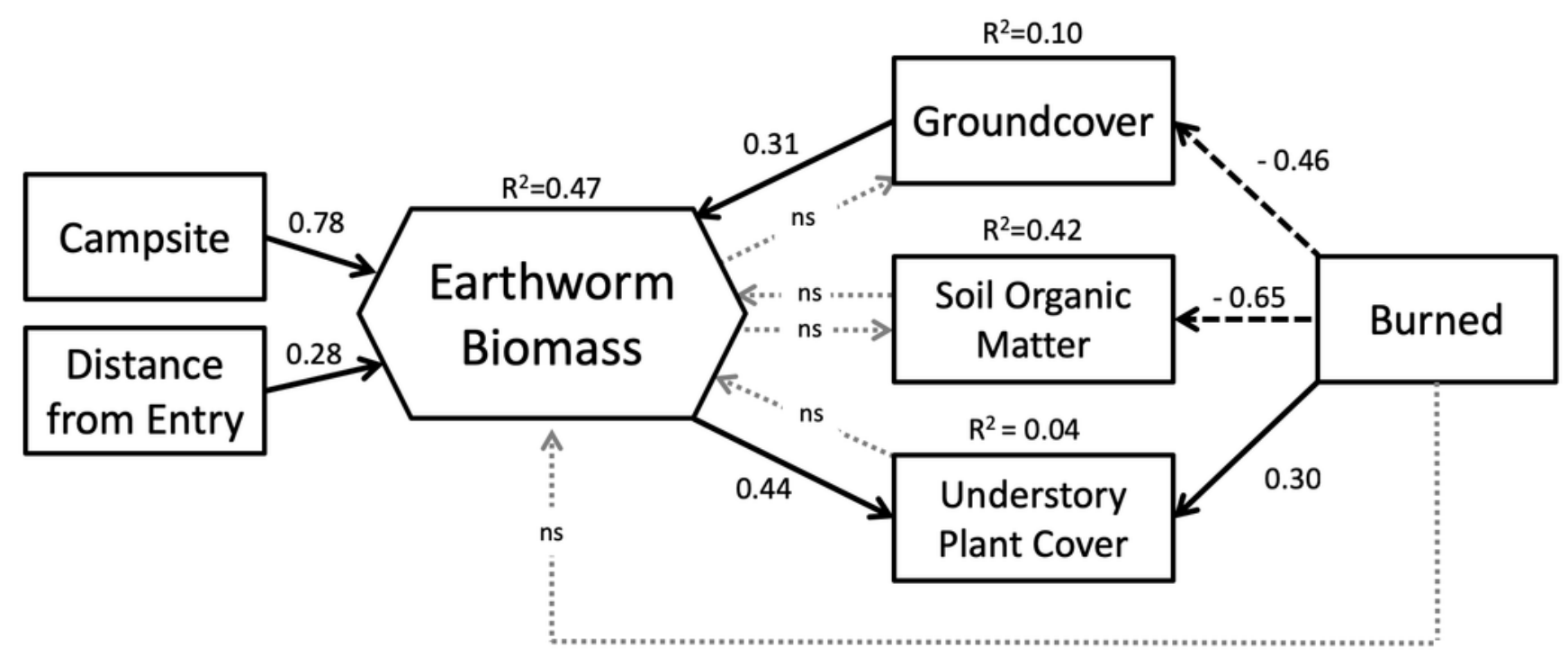

